\title{
"Travel and tourism: growth potentials and contribution to the GDP of Saudi Arabia"
}

\begin{tabular}{|c|c|}
\hline AUTHORS & Anis Ali iD https://orcid.org/0000-0001-7799-6043 \\
\hline ARTICLE INFO & $\begin{array}{l}\text { Anis Ali (2018). Travel and tourism: growth potentials and contribution to the } \\
\text { GDP of Saudi Arabia. Problems and Perspectives in Management, 16(1), 417- } \\
\text { 427. doi:10.21511/ppm.16(1).2018.39 }\end{array}$ \\
\hline DOI & http://dx.doi.org/10.21511/ppm.16(1).2018.39 \\
\hline RELEASED ON & Monday, 02 April 2018 \\
\hline RECEIVED ON & Monday, 13 November 2017 \\
\hline \multirow[t]{2}{*}{ ACCEPTED ON } & Friday, 23 February 2018 \\
\hline & $((c))$ EY \\
\hline LICENSE & $\begin{array}{l}\text { This work is licensed under a Creative Commons Attribution } 4.0 \text { International } \\
\text { License }\end{array}$ \\
\hline JOURNAL & "Problems and Perspectives in Management" \\
\hline ISSN PRINT & $1727-7051$ \\
\hline ISSN ONLINE & $1810-5467$ \\
\hline PUBLISHER & LLC "Consulting Publishing Company "Business Perspectives" \\
\hline FOUNDER & LLC "Consulting Publishing Company "Business Perspectives" \\
\hline
\end{tabular}

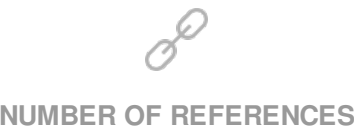

14

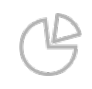

NUMBER OF FIGURES

0

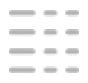

NUMBER OF TABLES

3

(C) The author(s) 2022. This publication is an open access article. 


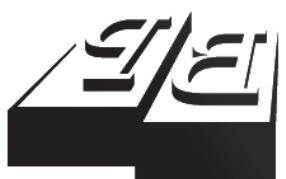

BUSINESS PERSPECTIVES

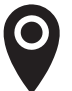

LLC "CPC "Business Perspectives" Hryhorii Skovoroda lane, 10, Sumy, 40022, Ukraine

www.businessperspectives.org

Received on: $13^{\text {th }}$ of November, 2017 Accepted on: $23^{\text {rd }}$ of February, 2018

(C) Anis Ali, 2018

Anis Ali, Ph.D., Assistant Professor, Department of Management, Prince Sattam Bin Abdulaziz University, Saudi Arabia.

\section{TRAVEL AND TOURISM: GROWTH POTENTIALS AND CONTRIBUTION TO THE GDP OF SAUDI ARABIA}

\begin{abstract}
Saudi Arabia is well known in the world for the holy places Makkah and Madinah. Hajjis and visitors come to perform hajj and Umrah every year in Makkah and Madinah from all around the world. Hajj and Umrah visits play a vital role in the inbound tourism of Saudi Arabia. The tourism revenue of Kingdom of Saudi Arabia is increasing absolutely but losing its contribution to the GDP proportionately. So, this paper tries to find out the economic activities of all components of tourism sector which are responsible for the negative trend. It also explains the relationships and variability of tourism revenues and expenditures with GDP and offers suggestions to enhance revenue of tourism sector. This study is based upon secondary data obtained from the website of SAMA (Saudi Arabian Monetary Authority) and General Authority for Statistics of Saudi Arabia. In tourism sector of Saudi Arabia, the increasing trend of expenditures of some economic activities is more than its revenue. The increasing trend of expenditures comparatively its revenues lowering contribution of tourism towards GDP. To improve the level of tourism revenue, government has to provide world class facilities and develop new tourist spots and allow the visitors to visit such places according to the Shariah and Kingdom rules. Government has to focus on developing passenger rail transport and other means of transport to connect all the tourist spots to provide easy conveyance, and on improving and developing tourism sector by helping the government and private organizations that are engaged directly or indirectly in providing services to the domestic and inbound tourists to assure more contribution to GDP.
\end{abstract}

Keywords

tourism, Saudi Arabia, inbound and outbound tourism, GDP, economy

\section{JEL Classification $\quad$ L38, Z32}

\section{INTRODUCTION}

Travel and tourism is to be considered as an important economic activity around the world and contributing directly and indirectly to the economies. According to UNWTO (World Tourism Organization), tourism sector played a significant role during last decade. Nowadays, tourism is to be considered as main stream of the business activities. Tourism is being developed as an organized sector, providing employment and contributing to economic growth. In all economies, tourism affects and creates utility in culture, education, transportation, infrastructure, communications, and health (Mohammed Al Yousif \& Ahmed Al Bakr, 2017). According to UNWTO, tourism is "a set of activities carried out by a person traveling to a place outside his/ her usual environment for at least one night, but less than a year, and whose main purpose of travel is other than the exercise of an activity remunerated from within the place visited". Moving from one place to another place for at least one night but not more than a year for non-economic activities is to be considered tourism. There are three types of tourism, i.e. domestic tourism, inbound tourism and outbound tourism. In domestic tourism, traveler goes to visit another dhis is an Open Access article, distributed under the terms of the Creative Commons Attribution 4.0 International license, which permits unrestricted re-use, distribution, and reproduction in any medium, provided the original work is properly cited. 
place/places within the country. In inbound tourism, travelers of other nations come to visit place/ places of the country for non-economic purposes. Outbound tourism considers the nationals moving outside of the country for visiting purposes. In Saudi Arabia, Makkah and Madinah are pilgrim places and as per Islamic provisions, visit of both places is necessary for all Muslims at least once in a whole life. In Saudi Arabia, most of the visitors are coming to visit only Makkah and Madinah. The potential growth of Saudi Tourism sector is lower than the average of world tourism sector. There is need to enhance the level of tourism in Saudi Arabia as the Saudi economy is based upon petroleum products and international demand and prices of products being down day by day. Shifting from Oil-based economy to Non-oil economy is very necessary to maintain or enhance GDP. At worldwide level, the Direct and Total contribution of travel and tourism to the GDP was USD 2,306.0 bln (3.1\% of total GDP) and USD $7,613.3 \mathrm{bln}(10.2 \%$ of GDP) in 2016 . All over the world, total employment directly provided by the travel and tourism sector in the year 2016 was $108,741,000$ jobs amounted $3.6 \%$ of total employment. Travel and tourism sector of the world is providing totally $9.6 \%$ jobs. Apart from this, visitor exports generated USD $1,401.5$ bln (6.6\% of total exports) in 2016. There is $3.8 \%, 3.6 \%$ and $3.6 \%$ rise expected in the direct contribution, total contribution to GDP and level of employment in the year 2017 (Travel and tourism economic impact world 2017). At worldwide level in tourism sector, direct contribution, total contribution and employment level are expected to increase in future and contribute positively to the economies.

In Saudi Arabia, petroleum products contribute significantly to economic growth and development of the nation. As per Wikipedia, petroleum sector of Saudi Arabia contributes $92.5 \%$ of budget revenues, $55 \%$ of GDP, and $97 \%$ export earnings. Since last 70 years, according to Economic Research Department of Saudi Arabia, the oil prices increased by 9 times approximately. In Saudi Arabia, the Direct and Total contribution of travel and tourism to the GDP was SAR $78.8 \mathrm{bln}$ (USD $21.0 \mathrm{bln}-3.3 \%$ of total GDP) and SAR 244.6 bln (USD $65.2 \mathrm{bln}-10.2 \%$ of GDP) in 2016. In Saudi Arabia, total employment provided by the travel and tourism sector in the year 2016 was 603,500 jobs which are $5.1 \%$ of total employment. Travel and tourism sector of Saudi Arabia is providing totally 9.7\% jobs. Apart from this, visitors generated SAR 43.0 bln (USD $11.5 \mathrm{bln}$ ) which is $5.8 \%$ of total exports in 2016 . There is $2.9 \%, 6.4 \%$ and $1.6 \%$ rise expected in the direct contribution and total contribution to GDP and level of employment in the year 2017 (Travel and tourism economic impact, Saudi Arabia, 2017). In Saudi Arabia, tourism sector, direct contribution, total contributions to GDP and employment level are expected to increase in future and contribute positively to the economies. Saudi Arabia's tourism sector is contributing to GDP of the economy in all ways more than the average of world level tourism. In future, the world tourism sector is expecting $4 \%, 3.9 \%, 2.2 \%$ and $2.5 \%$ rise annually in direct contribution to GDP, total contribution to GDP, and direct employment total contribution in the year 2017. The tourism sector of Saudi Arabia is expecting $3.8 \%, 4.7 \%, 2.5 \%$ and $3 \%$ rise annually in direct contribution to GDP, total contribution to GDP, direct employment total contribution in the year 2017 (Estimates of Travel and tourism economic impact, Saudi Arabia, 2017).

In Saudi Arabia, there is need to focus on the visitors generated exports as it is $5.8 \%$ of total exports lower than the average of world tourism generated exports (6.6\% of total exports). The rise expectancy of Tourism of Saudi Arabia is more than average of world tourism except direct contribution to GDP (as mentioned above). The direct contribution of tourism of Saudi Arabia should be encouraged to get equality of world level contribution of tourism towards GDP of Saudi Arabia. The contribution of travel and tourism sector of Saudi Arabia can be extended after exploring new dimensions of tourism.

\section{LITERATURE REVIEW}

Alqahtani and Saba (2014) state that insufficient awareness, low positive consideration and poor advertisement, low transparency, multiple pric- ing system, ineffective and poor communication flow, misconception and no surety about the roles and responsibilities of authority are the main challenges facing the growth of the sector (tourism) in the country. This study suggests that 
the introduction of the social Customer Relation Management strategy will help to improve and maintain the relations of authority and public and help in designing, planning, execution and delivery of tourism services in the country. Mufeed (2014) advocated that government as well as airlines, hotels and travel agents have to work to develop and improve the infrastructure of various tourist places and to encourage foreigners to visit these places by providing best facilities and ease in attaining the visa for the foreigners. Aleidan (2017) indicates that Saudi Arabia has formulated and enforced a new tourism law to develop its tourism sector with special emphasis to open more international activities in the hotel industry; it will help tourism and ultimately Saudi economy. Damanhouri (2017) found that the friendly environment and supportive people, convenience in communication, restaurant and accommodation services and especially the government support to ensure that there is no lag in government activities for tourists, affect tourists positively. He further recommended in his study the following intercity and Makkah rail facility, government bus facility from haram to hotels of the tourists, easy availability of hospitals and dispensary, health and hygiene during hajj, recycling of ploy pack and bottles, etc. Tambo (2017) explained the necessity of positioning smart tourism and hospitality model for economic transformation in Saudi Arabia by building solid partnership and collaboration model holds great promises and opportunities to improve economy growth and Saudization programs in achieving the vision 2030's priorities and targets. Tambo further suggested tourism promotion and hospitality expansion and enabling environment, maintaining standards, professional ethics and best practices are needed to provide quality of services and innovative packages satisfaction of pilgrims and visitors. Alam and Malik (2016) stated in their study that government has to come up with policies for further development and tourism for the years to come. Mohammed Al Yousif, A.B.D. and Ahmed Al Bakr (2017) revealed that Saudi Arabia has been considering investment in the tourism industry very seriously as one of the primary methods for economic diversification. Further the authors stated that the Saudi tourism sector suffers from some structural issues, i.e. foreign workers in- tensively engage in construction and service activities that account for a significant part of the tourism industry and suggested increasing Saudi workers' productivity and encouraging small and medium sized enterprises (SMEs) in tourism sector. According to Alhowaish (2016), given the fact that GCC countries have similar climate and natural resources, attracting international tourists may require some degree of specialization to offer unique services and activities. GCC policymakers intended to establish an intra-GCC tourism-oriented approach with the goal of enhancing GCC countries as a tourist destination. Policymakers should formulate their tourism policy based on country-specific comparative advantages, rather than competitive advantages. Ohlan (2017) found in his studies that government support forming new policies to help tourism and new talent in human resource capital is necessary for the development of tourism sector to contribute to economic development of the Indian economy. There is a positive relationship between tourism spending and economic growth in Saudi Arabia. The development of tourism sector will thus have a positive impact on the growth of the Saudi economy (Ageli \& Moosa, 2013). Satisfaction plays a vital role in the service sector and enhances the productivity of the business. Ali and Ratwani (2017) explained that consideration of special needs of the customers is necessary to enhance satisfaction level of customers in the service sector.

The main objective of the study is to analyze the tourism sector of Saudi Arabia post economic recession of the world economy and get the trend and reveal the negative performing economic activity to facilitate economic development. The following are the specific objectives for this analytical and secondary data based study.

1. To recognize trends of various activities of components of Saudi Arabia's tourism sector.

2. To establish relationship between tourism revenue and the rest dependent components of Saudi Arabia's tourism sector.

3. To get negative performance of tourism sector and provide suggestions to assure tourism contribution to the GDP of Saudi Arabia. 


\section{RESEARCH PROBLEMS}

Tourism industry is the main component for the service sector of any economy. In Saudi economy, the international demand for the petrochemical products is being down year by year. So, economy has to shift from the oil sector to other sectors. In Saudi Arabia, there is ample amount of potentials available in different industries of service sector. Tourism is the most pure service and a lot of scope is there in the tourism industry. However, no study is available revealing the trend of various economic activities and its depth analysis. Therefore, the present study focuses upon the various aspects of the facts and figures of tourism industry in Saudi Arabia. Hence, the study tries to get positive and negative performances of all the economic activities to provide suggestions for better performance.

\section{RESEARCH METHODOLOGY}

This research is based upon the secondary data obtained from the website of General Authority for Statistics of Saudi Arabia and SAMA (Saudi Arabian Monetary Authority). The tourism data are to be analyzed to get the trend and contribution to GDP of Saudi Arabia. The 2010 data of tourism sector are to be considered as base for this study. The fixed base index numbers are calculated to get the trend of all economic activity of the tourism sector. The average trend indices are calculated for each economic activity of all tourism sector components (Revenue, expenditure, compensation, employees - Saudi \& Non-Saudi and establishments) of Saudi Arabia to know the average increment from 2010 to 2015.

The following formula is to be used in this analysis to get average trend indices which are based upon fixed base indices.

$$
A T I_{F B I}=\frac{\sum F B I}{N}
$$

where $A T I_{F B I}$ - average trend indices, $\sum F B I$ sum of FBI of activity for years under consideration, $N$ - number of years under consideration.

Average trend indices are the base to calculate correlation $(r)$ between the tourism revenue and rest components of tourism (Appendix 1) and to study the variability within a component of all economic activities. In tourism sector of Saudi Arabia, there are seven components considered for the study, i.e revenue, expenditures, compensation, employees, Saudi employees, non-Saudi employees and establishments (as it is available in GAS publication of tourism from 2010 to 2015). The correlation between all economic activities of revenue, expenditure of tourism sector and GDP of Saudi Arabia is calculated to know the effect of economic activities of tourism on the GDP of Saudi Arabia. Average of FBI (Fixed Base Indices) is calculated to get trends which reveals the average growth of each economic activity of all components of tourism sector in Saudi Arabia (trends available in Appendix 1 for each activity of all components). The average trends of each economic activity of all components are correlated with revenue to know the relationship between tourism revenue and other components of tourism sector. The average index numbers of all economic activities of tourism revenues and tourism expenditures are compared to know the negative performing activities relatively. The variability (coefficient of variation) of average trend indices of each economic activity is calculated to get the equality in incremental trend (Table 1). The impact of tourism revenue and expenditure on GDP is studied to know the contribution to the economy of Saudi Arabia. Chain based index numbers of revenue, expenditures and GDP are calculated to study the contribution to and impact on GDP. To get the contribution or impact on GDP, correlation coefficients are to be calculated between revenue and GDP and expenditure and GDP (Tables 2 and 3).

\subsection{Limitations of the study}

This study is purely based upon secondary data obtained from websites of Saudi Arabia. Data available on General authority for statistics website are only for a limited period (2010 to 2015). The collection of primary information regarding the travel and tourism from the tourists and other concerning organizations is not easily available as the researcher does not belong to the Kingdom of Saudi Arabia. The results might be different or misleading due to no consideration of primary information, resulting in ambiguity defining the negativity of the economic activities of the different aspects of the concerned tourism sector. 
Table 1. Results of analysis

Source: Tourism publication of General Authority for Statistics website of Saudi Arabia, 2010-2015.

\begin{tabular}{|c|c|c|c|c|c|c|c|}
\hline \multirow{2}{*}{$\begin{array}{l}\text { Statistical } \\
\text { tools }\end{array}$} & \multicolumn{7}{|c|}{ Components of tourism sector } \\
\hline & Revenue & Expenditure & Compensation & $\begin{array}{c}\text { Total } \\
\text { employees }\end{array}$ & $\begin{array}{l}\text { Non-Saudi } \\
\text { employees }\end{array}$ & $\begin{array}{c}\text { Saudi } \\
\text { employees }\end{array}$ & Establishments \\
\hline $\begin{array}{l}\text { Standard } \\
\text { deviation }(\sigma)\end{array}$ & 21.67898081 & 20.56600229 & 20.56600229 & 23.76823116 & 20.41459241 & 20.36207247 & 20.6402733 \\
\hline Mean & 101.1311957 & 99.76691322 & 99.76691322 & 116.3570975 & 99.92510442 & 99.65208871 & 100.816125 \\
\hline $\begin{array}{l}\text { Coefficient } \\
\text { of variation }\end{array}$ & 0.214364921 & 0.206140509 & 0.206140509 & 0.204269715 & 0.204298935 & 0.204331617 & 0.20473187 \\
\hline $\begin{array}{l}\mathrm{H} 0, \text { Accepted } \\
\text { if } \mathrm{C} \vee \leq 1\end{array}$ & Accepted & Accepted & Accepted & Accepted & Accepted & Accepted & Accepted \\
\hline
\end{tabular}

Note: All the calculations are made on the basis of average index numbers of all economic activities of different components of tourism sector of Saudi Arabia. In Appendix 1, index numbers are given of each economic activity for all components of tourism sector of Saudi Arabia.

\subsection{Hypotheses of the study}

The hypotheses of the study are as follows:

H1: $\quad$ There is no significant incremental difference between all the economic activities of tourism revenue of Saudi Arabia.

H2: There is no significant incremental difference between all the economic activities of tourism expenditure of Saudi Arabia.

H3: There is no significant incremental difference between all the economic activities of tourism compensation of Saudi Arabia.

H4: There is no significant incremental difference in the total employees engaged in all economic activities of the tourism sector of Saudi Arabia.

H5: There is no significant incremental difference in the non-Saudi employees engaged in all economic activities of the tourism sector of Saudi Arabia.

H6: There is no significant incremental difference in the Saudi employees engaged in all economic activities of the tourism sector of Saudi Arabia.

H7: $\quad$ There is no significant incremental difference in the establishments related to all economic activities of the tourism sector of Saudi Arabia.

H8: There is no significant difference between the proportionate raising of tourism revenue and GDP in Saudi Arabia.
H9: There is no significant difference between the proportionate raising of tourism expenditure and GDP in Saudi Arabia.

\section{DATA INTERPRETATION AND ANALYSIS}

From the above study it is clear that the coefficient variations of all economic activities of all components of tourism sector in Saudi Arabia are lesser than 1 . So, there are no significant incremental differences between the all economic activities of all components of tourism sector in Saudi Arabia for the period 2010 to 2015 . Hence, hypotheses1, 2, $3,4,5,6$, and 7 are accepted.

This reveals that all the economic activity have the same proportion contribution or existence in all components of tourism sector for the period 2010 to 2015.

From the above analysis it can be explained that the contribution of tourism revenue decreases from year to year. In 2010, tourism revenues' contribution in Saudi Arabian GDP was 5.67\% and decreased by $12.70 \%$ (4.95\% contribution of revenue to Saudi GDP in 2015) in the year 2015. Although, the absolute amount of tourism revenue got increased by $11.60 \%$ since 2010 , but there was $27.60 \%$ increment in the GDP of Saudi Arabia from the 2010 to 2015 (GDP, 1,975,543,000 thousands SR in 2010 and 2,520,802,000 thousands SR in 2015). GDP of Saudi Arabia is increasing more proportionately than Tourism revenue and the tourism revenue is losing its contribution year by year. For the period 2010 to 2015, the correlation coef- 
Table 2. Tourism revenue and GDP of Saudi Arabia

Source: General Authority for Statistics and GDP from SAMA websites.

\begin{tabular}{|c|c|c|c|c|c|c|}
\hline Years & $\begin{array}{c}\text { Tourism sector } \\
\text { revenue ('000 } \\
\text { SR) } \\
\end{array}$ & GDP ('000 SR) & $\begin{array}{c}\text { Tourism } \\
\text { revenue, \% of } \\
\text { GDP }\end{array}$ & $\begin{array}{l}\text { Trend of tourism } \\
\text { revenue, \% of } \\
\text { GDP (ATI) }\end{array}$ & $\begin{array}{l}\text { Chain based } \\
\text { index of tourism } \\
\text { revenue }\end{array}$ & $\begin{array}{l}\text { Chain based } \\
\text { index of GDP }\end{array}$ \\
\hline 2010 & $111,920,988$ & $1,975,543,000$ & 5.665327862 & 100 & 100 & 100 \\
\hline 2011 & $113,353,040$ & $2,172,286,000$ & 5.218145309 & 92.10667831 & 101.2795205 & 109.9589328 \\
\hline 2012 & $115,961,969$ & $2,289,252,000$ & 5.065496022 & 97.07464478 & 102.301596 & 105.3844659 \\
\hline 2013 & $119,135,895$ & $2,350,373,000$ & 5.068808015 & 100.0653834 & 102.7370405 & 102.6699114 \\
\hline 2014 & $121,149,055$ & $2,435,896,000$ & 4.973490453 & 98.11952708 & 101.6898014 & 103.638699 \\
\hline 2015 & $124,914,581$ & $2,520,802,000$ & 4.955350757 & 99.63527234 & 103.1081761 & 103.4856168 \\
\hline$r$ & \multicolumn{2}{|c|}{+0.95} & - & - & \multicolumn{2}{|c|}{+0.15} \\
\hline
\end{tabular}

ficients between the absolute amounts of tourism revenue and GDP, chain base indices of tourism revenue and GDP are 0.95 and 0.15 , respectively (Table 2). It reveals the strong long-term positive relationship between tourism revenue and GDP, while short-term or yearly fluctuations of tourism revenue are not significant due to its contributing only around 5\% to GDP. The coefficient of variation of tourism revenue and GDP in Saudi Arabia is 0.038 and 0.057 , respectively (Appendix 2). It reveals that there is stagnation in the tourism revenue as compared to GDP.

Hypothesis 8 should be accepted.

However, there is a minute difference between the proportionate raising of tourism revenue and GDP of Saudi Arabia as per the coefficient variation of tourism revenue and GDP and increasing trend of tourism revenue and GDP in Saudi Arabia.

From the above analysis it can be explained that the tourism expenditure decreases every year, proportionately. In 2010, tourism expenditure in Saudi Arabian GDP was 2.69\% and decreased by $13 \%$ (2.34\% expenditure to Saudi GDP in 2015) in the year 2015. Although, the absolute amount of tourism expenditure got increased by $11 \%$ since 2010, but there was $27.60 \%$ increment in the GDP of Saudi Arabia as from 2010 (GDP, 1,975,543,000 thousands SR in 2010 and 2,520,802,000 thousands SR in 2015). GDP of Saudi Arabia is increasing more proportionately than Tourism expenditure and the tourism expenditure is decreasing year by year. For the period 2010 to 2015 , the correlation coefficients between the absolute amounts of tourism expenditure and GDP, chain base indices of tourism revenue and GDP are 0.90 and 0.17 , respectively (Table 3 ). It reveals the strong long term positive relationship between tourism expenditure and GDP, while short-term or yearly fluctuations of tourism expenditure are not effecting significantly due to low amount of only around $2.5 \%$ equal to GDP. The coefficient of variation of tourism revenue and GDP of Saudi Arabia is 0.035 and 0.057 , respectively (Appendix 2). It reveals there is stagnation in the tourism expenditure as compared to GDP.

Hypothesis 9 should be accepted.

However, there is a minute difference between the proportionate raising of tourism expenditure and GDP of Saudi Arabia as per the coefficient varia-

Table 3. Tourism expenditure and GDP of Saudi Arabia

Source: General Authority for Statistics and GDP from SAMA websites.

\begin{tabular}{|c|c|c|c|c|c|c|}
\hline Years & $\begin{array}{c}\text { Tourism sector } \\
\text { expenditure } \\
(000 \mathrm{SR})\end{array}$ & GDP ('000 SR) & $\begin{array}{l}\text { Tourism sector } \\
\text { expenditure, \% } \\
\text { of GDP }\end{array}$ & $\begin{array}{l}\text { Trend of tourism } \\
\text { expenditure, \% } \\
\text { of GDP }\end{array}$ & $\begin{array}{l}\text { Chain based } \\
\text { index of tourism } \\
\text { expenditure }\end{array}$ & $\begin{array}{l}\text { Chain based } \\
\text { index of GDP }\end{array}$ \\
\hline 2010 & $53,128,431$ & $1,975,543,000$ & 2.68930775 & 100 & 100 & 100 \\
\hline 2011 & $54,010,641$ & $2,172,286,000$ & 2.48635037 & 92.45317388 & 101.6605233 & 109.9589328 \\
\hline 2012 & $54,640,721$ & $2,289,252,000$ & 2.386837316 & 95.99762548 & 101.1665849 & 105.3844659 \\
\hline 2013 & $55,235,205$ & $2,350,373,000$ & 2.350061246 & 98.45921335 & 101.0879871 & 102.6699114 \\
\hline 2014 & $56,083,539$ & $2,435,896,000$ & 2.302378221 & 97.97098802 & 101.5358574 & 103.638699 \\
\hline 2015 & $58,978,909$ & $2,520,802,000$ & 2.339688282 & 101.6205009 & 105.1626022 & 103.4856168 \\
\hline$r$ & +0.90 & & - & - & +0.17 & \\
\hline
\end{tabular}


tion of tourism expenditure and GDP and increasing trend of tourism expenditure and GDP in Saudi Arabia.

\section{TREND ANALYSIS OF EACH ECONOMIC ACTIVITY OF ALL COMPONENTS OF TOURISM SECTOR IN SAUDI ARABIA}

From the analysis of average fixed base index numbers of each activity of the tourism sector it can be explained that some revenue activities are performing positively compared with related expenditure of the same activity. Inland passenger water transport, short-term accommodation activities, other sports activities, other amusement and recreation activities n.e.c., renting and leasing of recreational and sports goods are performing positively and their average trend is more increasing than relative expenditures of economic activity. Rest economic activities of the tourism sector revenues of the Kingdom are either performing negatively or equal to the related expenditure of tourism revenue (Appendix 1). So, it is critical to control all the expenditures and increase in the revenues of all economic activities but specially focusing upon passenger rail transport interurban, urban and sub-urban passenger land transport, other passenger land transport, passenger air transport, other accommodation, beverage serving activities, real estate activities on a fee or contract basis, creative arts and entertainment activities, operation of sports facilities, activities of amusement parks and theme parks (Appendix 1). The employees engaged in tourism activities are increased in all economic activities by more than $20 \%$ on an average of 2010 to 2015 . This indicates that tourism is playing a vital role in providing jobs in all economic activities (Appendix 1). The non-Saudi and Saudi employees increased by $22.05 \%$ and $8.64 \%$ in passenger rail transport, interurban economic activities significantly and rest economic activities are evident of a normal increment. The all establishments of tourism sector noted growth and development except passenger rail transport, interurban and inland passenger water transport. The compensation of the employ- ees is increasing normally in all economic activities. But, only in passenger rail transport, interurban activity of compensation increases by $18 \%$ in the period 2010-2015 (Appendix 1). The long-term correlation between tourism revenue and all the economic activities is strongly positive (Appendix 1) revealing the direct effect of all components of tourism on tourism revenue.

\section{RESULTS OF THE STUDY}

From the above analysis of all economic activities of all components of tourism sector it can be concluded that all the economic activities contribute equal proportion every year or in all components of the Tourism sector for the period 2010 to 2015. GDP of Saudi Arabia is increasing more proportionately than Tourism revenue and the tourism revenue is losing its contribution in GDP year by year. Although, there is a minute difference between the proportionate raising of tourism revenue and GDP in Saudi Arabia (as per the coefficient variation of tourism revenue and GDP and increasing trend of tourism revenue and GDP of Saudi Arabia). GDP of Saudi Arabia is increasing more proportionately than tourism expenditure and the tourism expenditure is decreasing year by year. There is a minute difference between the proportionate raising of tourism expenditure and GDP of Saudi Arabia as per the coefficient variation of tourism expenditure and GDP and increasing trend of tourism expenditure and GDP of Saudi Arabia. This is a good indication that tourism of Saudi Arabia is utilizing its resources very well to maximize revenue from all economic activities and comparatively controlling over the expenditures. The trend of average amount of all components, i.e. inland passenger water transport, short-term accommodation activities, other sports activities, other amusement and recreation activities n.e.c., renting and leasing of recreational and sports goods are performing positively and their average trend is more increasing than relative expenditure of economic activity and remaining economic activities of tourism revenue performances are lower than expenditure, i.e. passenger rail transport - interurban, urban and sub-urban passenger land transport, other passenger land transport, passenger air transport, other accommodation, beverage serving activities, real estate 
activities on a fee or contract basis, creative arts and entertainment activities, operation of sports facilities, activities of amusement parks and theme parks (Appendix 1). Compensation for tourism sector economic activity is increasing rapidly as compared to compensation for rest activities of tourism sector (Appendix 1).

On an average, tourism sector employees increased by $20 \%$ from 2010 to 2015 . The average increment of Saudi employees engaged in passenger rail transport, interurban increased rapidly than Saudi employees engaged in other activities of tourism or non-Saudi employees engaged in all activities of tourism in Saudi Arabia. The all establishments of tourism increased by $5 \%$ approximately (on an average for the period 2010 to 2015) except passenger rail transport, interurban and inland passenger water transport (Appendix 1).

\section{DISCUSSION}

As the tourism revenue is losing its contribution proportionately to GDP (Table 2), some efforts by decision makers are required to boost the level of tourism revenue. For instance, governments should build the required infrastructure such as hotels, services and roads. They can also modify existing infrastructures (Krapf, 1961). To make more revenue generated, tourism sector has to attract tourists from developed countries to obtain hard currency and it will increase the level of revenue. Making relationship with other countries is another step to improve the level of inbound tourism (Timothy, 2002). Normally, there are some other factors existing in tourism sector of Saudi Arabia, which might be negative for the tourism sector development. Alqahtani and Saba (2014) suggest the introduction of the social Customer Relation Management (CRM) strategy, which will help to improve and maintain the relations of authority and public and help in designing, planning, execution and delivery of tourism services in the country. To boost the level of inbound tourism, there should be some attractive offers for the foreign visitors, especially in Makkah and Madinah. In making world class tourism, promotion of tourism and hospitality expansion and enabling environment, maintaining standards, professional ethics and best practices are very necessary. The workforce involved in tourism activity should be well trained and skilled and governing of the tourism activities should be well managed to avoid any inconvenience to the visitors, who are coming from different places (Tambo, 2017). The internet connectivity is another factor that connects tourists with their family and friends. So, there is need to enhance the level of tourism by providing world class services and facilities to the visitors who are coming from different countries for visiting purposes. In this regard, new internet connectivity technologies WiFi, WiMax etc., are necessary to feel them connected round the clock (Al-Khalidi \& Kuppuswamy, 2014).

\section{CONCLUSION}

This analysis of tourism sector of Kingdom of Saudi Arabia observed that there is revenue of tourism losing its proportion in the GDP. The control is needed over all expenditures to enhance the level of all revenues to make more margin, but intensive focus is required on passenger rail transport interurban, urban and sub-urban passenger land transport, other passenger land transport, passenger air transport, other accommodation, beverage serving activities, real estate activities on a fee or contract basis, creative, arts and entertainment activities, operation of sports facilities, activities of amusement parks and theme parks. To enhance the level of tourism revenue, government has to provide the world class facility to attract the visitors from the developed countries to get hard currency. The tourism authority of Saudi Arabia can develop new tourist spots and allow inbound tourists to visit such spots under the Shariah and Kingdom rules. Government has to focus upon developing passenger rail transport and means of transport to connect all the tourist spots to provide easy conveyance. Above all, government has to focus upon improving and developing tourism sector by helping the government and private organizations that are engaged directly or indirectly in providing services to the domestic and inbound tourists. Makkah and Madinah are the world known holy places for the Muslims. Other tour- 
ist spots should be developed under the Shariah rules and rules of the Kingdom to attract visitors from all around the world. Except all, tourism sector has to focus upon easy availability of net connectivity facility, i.e. WiFi and WiMax etc., and well trained staff engaged in tourism hospitality to enhance the level of tourism. This analysis is purely based upon secondary data obtained from the websites of GAS (General Authority for Statistics) and SAMA (Saudi Arabian Monetary Authority) of Saudi Arabia. So, there is scope for the further research to get the opinion from the domestic and inbound tourists about the available services and facilities and their expectations to make tourism industry of Saudi Arabia more successful.

\section{REFERENCES}

1. A.B.D, M., \& Al Bakr, A. (2017). Tourism Development Effect On Saudi Economic Diversification. Economic Research Department Saudi Arabian Monetary Authority, 1-19. Retrieved from http:// www.sama.gov.sa/enUS/EconomicResearch/WorkingPapers/ Tourism\%20Development $\% 20$ Effect\%20On\%20Saudi\%20Economic\%20Diversification.pdf

2. Ageli, \& Moosa, M. (2013). Tourism Economics in Saudi Arabia: PP-VAR Approach. Asian Journal of Business and Management, 1(1), 21-27. Retrieved from https:// www.ajouronline.com/index.php/ AJBM/article/viewFile/126/137

3. Alam, A., \& Malik, E. (2016). The relationship between tourism, foreign direct investment and economic growth: evidence from Saudi Arabia. EUROPEAN ACADEMIC RESEARCH, 4(4), 4091-4106. Retrieved from http:// fac.ksu.edu.sa/sites/default/files/ the_relationship_between_tourism_foreign_direct.pdf

4. Aleidan, M. (2017). Hotel Industry Regulations and Cross-Border Franchising: The Case of Saudi Arabia. International Journal of Business and Management, 12(9), 94-103. Retrieved from http://ccsenet.org/journal/index.php/ijbm/ article/view/69032/0

5. Alhowaish, A. K. (2016). Is Tourism Development a Sustainable Economic Growth Strategy in the Long Run? Evidence from GCC Countries. Sustainability, 8(605), 1-10. Retrieved from http://www. mdpi.com/2071-1050/8/7/605/htm

6. Ali, A., \& Ratwani, B. (2017). Customers' Satisfaction in Indian
Banks: Problems and Solutions. International Journal of Economic Research, 14(9), 69-76. Retrieved from http://serialsjournals. com/serialjournalmanager/ pdf/1502690104.pdf

7. Alqahtani, F. A., \& Saba, T. (2014). Social Customer Relation Management for Tourism in Saudi Arabia: A Case Study. Life Science Journal, 11(2), 143-160. Retrieved from https://www.researchgate. net/publication/289013381_Social_customer_relation_management_for_tourism_in_Saudi_ Arabia_A_case_study

8. Damanhouri, A. (2017). Study of the Social and Cultural Aspects of Saudi Tourists and Evaluate the Services Provided to Tourist of Saudi - An Applied Study for the Tourism Sector in the Kingdom of Saudi Arabia. International Business Research, 10(1), 153-162. Retrieved from https://econpapers.repec.org/scripts/redir. pf?u=http $\% 3 \mathrm{~A} \% 2 \mathrm{~F} \% 2 \mathrm{Fwww}$. ccsenet.org\%2Fjournal\%2Findex. php\%2Fibr\%2Farticle\%2Fview\%2 F65144\%2F35310;h=repec:ibn:ibrj nl:v:10:y:2017:i:1:p:153-162

9. Economy of Saudi Arabia, Wikipedia. Retrieved from https:// en.wikipedia.org/wiki/Economy_ of_Saudi_Arabia

10. Mufeed, S. A., \& Gulzar, R. (2014). Tourism in Saudi Arabia. Global Review of Research in Tourism, Hospitality and Leisure Management, 1(3), 167-178. Retrieved from http://globalbizresearch.org/ files/grrthlm_sa-mufeed_rafiagulzar-72519.pdf

11. Ohlan, R. (2017). The relationship between tourism, financial devel- opment and economic growth in India. Future Journal Business, 3 , 9-22. Retrieved from https://www. sciencedirect.com/science/article/ pii/S2314721017300063

12. Tambo, E. (2017). Smart Positioning Tourism and Hospitality Model for Economic Transformation in Saudi Arabia. Journal of Hospitality and Tourism, 15(1), 82-96. Retrieved from https:// www.researchgate.net/publication/317349217_Smart_positioning_of_tourism_and_hospitality_industry_model_in_economic_ transformation_in_Saudi_Arabia

13. Travel and tourism economic impact Saudi Arabia (2017). Retrieved from https://www. wttc.org/-/media/files/reports/ economic-impact-research/countries-2017/saudiarabia2017.pdf

14. Travel and tourism economic impact world (2017). Retrieved from https://www.wttc.org/-/media/files/ reports/economic-impact-research/ regions-2017/world2017.pdf 


\section{APPENDIX 1.}

\section{Correlation between average fixed base index numbers of revenue and other components and relatively negative and positive performing economic activities in Saudi Arabia tourism sector}

Source: General Authority for Statistics website, Saudi Arabia.

\begin{tabular}{|c|c|c|c|c|c|c|c|}
\hline Economic activity & 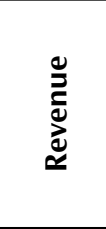 & 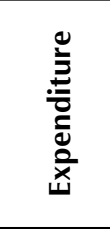 & 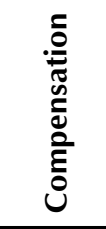 & $\frac{\mathscr{d}}{\frac{0}{\partial}}$ & 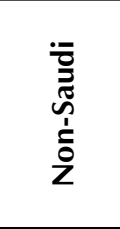 & : & 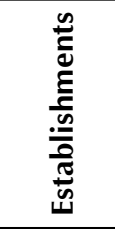 \\
\hline Passenger rail transport, interurban & 129.61 & 146.95 & 118 & 130.59 & 122.059 & 108.64 & 100 \\
\hline $\begin{array}{l}\text { Urban and sub-urban passenger } \\
\text { land transport }\end{array}$ & 98.78 & 105.86 & 106 & 121.79 & 104.25 & 105.32 & 106.522 \\
\hline Other passenger land transport & 101.35 & 103.38 & 103.42 & 121.33 & 104.294 & 103.85 & 106.79 \\
\hline $\begin{array}{l}\text { Sea and coastal passenger water } \\
\text { transport }\end{array}$ & 103.11 & 103.58 & 105.3 & 116.67 & 100.388 & 100 & 102.381 \\
\hline Inland passenger water transport & 116.42 & 103.43 & 105.76 & 120.59 & 103.896 & 101.52 & 100 \\
\hline Passenger air transport & 102.88 & 103.07 & 104.27 & 119.64 & 103.062 & 102.71 & 104.187 \\
\hline $\begin{array}{l}\text { Short-term accommodation } \\
\text { activities }\end{array}$ & \multicolumn{2}{|c|}{$\begin{array}{c}111.9 \\
105.16\end{array}$} & 104.6 & 120.66 & \multicolumn{2}{|c|}{$\begin{array}{c}103.371 \\
104.79\end{array}$} & 105.614 \\
\hline $\begin{array}{l}\text { Camping grounds, recreational } \\
\text { vehicle parks and trailer parks }\end{array}$ & 105.45 & 104.73 & 103.88 & 122.52 & 105.459 & 104.3 & 105.229 \\
\hline Other accommodations & 90.673 & 107.02 & 104.95 & 121.63 & 104.28 & 105.35 & 105.526 \\
\hline $\begin{array}{l}\text { Restaurants and mobile food } \\
\text { service activities }\end{array}$ & 106.89 & 104.76 & 105.94 & 123.68 & 106.133 & 103.88 & 107.768 \\
\hline Other food service activities & 105.46 & 104.07 & 104.05 & 121.5 & 104.411 & 103.93 & 103.333 \\
\hline Beverage serving activities & 102.86 & 104.38 & 104.07 & 120.26 & 103.227 & 103.38 & 104.28 \\
\hline $\begin{array}{l}\text { Real estate activities with own or } \\
\text { leased property }\end{array}$ & 103.23 & 103.02 & 105.84 & 119.71 & 102.882 & 102.53 & 106.351 \\
\hline $\begin{array}{l}\text { Real estate activities on a fee or } \\
\text { contract basis }\end{array}$ & 100.18 & 108.73 & 104.09 & 120.48 & 103.571 & 103.05 & 103.932 \\
\hline $\begin{array}{l}\text { Renting and leasing of motor } \\
\text { vehicles }\end{array}$ & 103.28 & 104.29 & 106.05 & 120.27 & 103.238 & 103.32 & 107.555 \\
\hline $\begin{array}{l}\text { Renting and leasing of recreational } \\
\text { and sports goods }\end{array}$ & 109.01 & 103.21 & 104.07 & 121.27 & 104.318 & 102.85 & 105.456 \\
\hline Travel agency activities & 105.32 & 104.02 & 104.79 & 121.07 & 104.068 & 103.39 & 104.764 \\
\hline Tour operator activities & 103.56 & 104.92 & 105.31 & 121.35 & 103.529 & 104.78 & 104.704 \\
\hline $\begin{array}{l}\text { Other reservation service and } \\
\text { related activities }\end{array}$ & 104.68 & 104.87 & 103.29 & 121.2 & 103.615 & 104.66 & 102.941 \\
\hline $\begin{array}{l}\text { Creative, arts and entertainment } \\
\text { activities }\end{array}$ & 102.91 & 105.64 & 103.43 & 120.8 & 103.15 & 104.99 & 102.868 \\
\hline $\begin{array}{l}\text { Museums activities and operation } \\
\text { of historical sites and buildings }\end{array}$ & 104.17 & 103.35 & 103.32 & 120.48 & 104.074 & 102.03 & 103.061 \\
\hline $\begin{array}{l}\text { Botanical and zoological gardens } \\
\text { and nature reserves activities }\end{array}$ & 105.48 & 104.63 & 104.09 & 121.88 & 104.416 & 105.04 & 104.065 \\
\hline Gambling and betting activities & 0 & 0 & 0 & 0 & 0 & 0 & 0 \\
\hline Operation of sports facilities & 103.53 & 105.35 & 105.13 & 121.35 & 104.324 & 103.85 & 105.482 \\
\hline Other sports activities & 104.25 & 94.112 & 104.43 & 120.28 & 102.894 & 103.68 & 106.173 \\
\hline $\begin{array}{l}\text { Activities of amusement parks and } \\
\text { theme parks }\end{array}$ & 104.4 & 105.03 & 107.16 & 121.48 & 104.431 & 103.89 & 107.455 \\
\hline $\begin{array}{l}\text { Other amusement and recreation } \\
\text { activities n.e.c. }\end{array}$ & 105.17 & 95.016 & 107.54 & 123.39 & 106.774 & 103.88 & 104.781 \\
\hline Total & 105 & 104.17 & 105.34 & 121.87 & 104.812 & 103.66 & 107 \\
\hline $\begin{array}{l}\text { Correlation between revenue and } \\
\text { other components }\end{array}$ & - & 0.95 & 0.9719 & 0.9656 & 0.97627 & 0.9559 & 0.93057 \\
\hline
\end{tabular}

Note: The average fixed index numbers are calculated from the data available on website of GAS of KSA for the period 20102015. The positive trends reflecting index numbers are in bold and italic while negatives are in bold only). 


\section{APPENDIX 2.}

\section{Coefficient of Variation (CV) of Tourism Revenue, Tourism Expenditures and GDP of Saudi Arabia}

Source: General Authority for Statistics \& SAMA website of Saudi Arabia.

\begin{tabular}{|c|c|c|c|}
\hline \multirow{2}{*}{ Statistical tools } & \multicolumn{3}{|c|}{$\begin{array}{c}\text { Coefficient of variation (CV) of tourism revenue, tourism expenditures and GDP } \\
\text { of Saudi Arabia }\end{array}$} \\
\hline & Revenue ('000 SR) & Expenditure ('000 SR) & GDP ('000 SR) \\
\hline Standard deviation $(\sigma)$ & 4491375.863 & 1939720.58 & 133935536.2 \\
\hline Mean $(x)$ & 118902908 & 55789803 & 2353721800 \\
\hline $\begin{array}{l}\text { Coefficient of variation } \\
\text { (CV) }\end{array}$ & 0.037773474 & 0.034768371 & 0.056903724 \\
\hline
\end{tabular}

Note: All the calculations are made on the absolute amounts of revenues and expenditures of tourism sector and GDP of Saudi Arabia for the period 2010-2015). 